\title{
A EDUCAÇÃO SENEQUIANA
}

José Joaquim Pereira Melo*

\section{RESUMO}

O presente trabalho tem como preocupação fazer algumas reflexões sobre o conceito de educação de Sêneca. A educação, para esse pensador, consistia na subordinação das tendências instintivas à razão, e a condição fundamental para essa sujeição era o conhecimento de si mesmo. Isto implica que, em sua concepção, o processo formativo tinha um caráter de auto-educação, cujos princípios fundamentais eram a moral, a virtude, a liberdade, a sabedoria e a filosofia. Assim, o pensamento de Sêneca deve ser abordado segundo dois eixos condutores significativos. O primeiro é que a sabedoria e a filosofia são realidades inseparáveis e diz respeito à meta da formação, ou seja, à educação "consumada"; o segundo, que tanto a filosofia como a sabedoria fazem parte da substância da educação e refere-se, ainda, ao objetivo imediato, instrumento e caminho para formação, quer dizer, a educação se "realizando".

PALAVRAS-CHAVE: Sêneca. Educação. Filosofia. Autoformação.

\section{ABSTRACT}

The present study is concerned with making some reflections about the education concept in Seneca. The education, for this thinker, consisted in the subordination of the instinctive trends to the reason,

Doutor em História e Sociedade e professor do DFE/PPE/UEM - Universidade Estadual de Maringá. 
and the essential condition for this subjection, was the knowledge of oneself. It implicates that, in his conception, the formative process had a character of self-education, which basic principles were moral, virtue, liberty, knowledge and philosophy. Therefore, Seneca's thinking must be treated according to two significant guiding lines: the first is that the knowledge and the philosophy are inseparable realities; the second is that philosophy as well as wisdom is part of the education essence. The first is about the formation target, or rather, the "consummate" education; the second refers to the immediate objective, instrument and road to formation, in other words, the "realization" of the education.

KEYWORDS: Seneca. Education. Philosophy. Self formation.

Lúcio Aneu Sêneca, político, escritor e filósofo na Roma do alvorecer da Era Cristã, conquistou notoriedade e lugar de destaque na História pela sua preocupação com a promoção do homem do seu tempo, o qual, segundo ele, era marcado pelo sofrimento decorrente de um ambiente de dissensões políticas, arbitrariedades, inseguranças e medos provocados por um Império em franca decadência.

Para Sêneca, a reordenação dessa sociedade passava, em grande medida, por um processo educativo que possibilitasse ao homem o desenvolvimento da racionalidade e de uma vida virtuosa e feliz, conforme a natureza lhe havia projetado.

Na realização dessa ação educativa, o que levaria à formação do sábio, do agente social que responderia às necessidades do seu tempo, não eram as habilidades intelectuais e a assimilação da cultura, mas a regeneração do homem. Por esse motivo, definiu a escola como "o lugar onde se investigam as qualidades do homem de bem, donde se aprende a sê-lo" (Cartas 76, 4).

Em face disto, são perfeitamente compreensíveis suas constantes críticas à educação de corte intelectual comprometida com a superficialidade, na qual se confundia cultura com sabedoria e instrução com educação. 
Esse era para Sêneca um dos grandes paradoxos da formação humana, uma vez que o fato de o discípulo assimilar conteúdos múltiplos sem ser por eles educado configurava-se como uma tragédia. Por isso, ele estabeleceu a distinção entre o homem "douto" e o homem "bom".

Mesmo destacando a "retidão", possibilitada pelo saber, Sêneca não deixou de lembrar os limites por ele estabelecidos, pois somente adentravam seus domínios aqueles que conseguiam captá-lo e respeitá-lo em sua plenitude. Essa condição representava a chave da formação liberal. Era necessário se libertar das coisas inúteis para que o espírito, num processo de busca, se fartasse da verdadeira sabedoria.

Segundo Sêneca esclareceu a Lucílio, o seu discípulo preferido, muitos dos conteúdos ensinados serviam apenas para aguçar o engenho humano, e lamentou-se: "Para que pretendes tu que eu te forneça uma ciência inútil?". Provocou, assim, uma solicitação do discípulo: "Ajuda-me, então, a ser capaz de desprezar os prazeres e a glória", "ensina-me apenas o indispensável" (Cartas 19, 17-18). Isso o levou a informá-lo o que se propunha a fazer nesse sentido e destacar as avaliações que poderiam ser feitas quanto ao exercício dos conhecimentos de caráter meramente "intelectualista".

Caro Lucílio, com estes subtis raciocínios, não conseguimos mais do que dar a aparência de exercitar o engenho com bagatelas e empregar os nossos ócios em discussões totalmente estéreis. Vou, no entanto, satisfazer o teu desejo e expor a opinião da nossa escola sobre o assunto (Cartas 113, 1).

Assim, mostrou a Lucílio a virtude do filósofo e da Filosofia e os benefícios que um e outro poderiam trazer aos seus convivas e adeptos:

De facto, quem convive diariamente com um filósofo obtém sempre algum beneficio: ou o seu caráter se aperfeiçoa, se torna mais apto a ou aperfeiçoar-se. O poder da filosofia beneficia inevitavelmente não só os iniciados, mas até os que a conhecem ocasionalmente (Cartas 108, 4). 
O filósofo, como homem, deveria também se preocupar consigo mesmo, mas sua preocupação primeira deveria ser promover e praticar a virtude, convertendo-se em exemplo. Por sua vez, a Filosofia deveria resultar num verdadeiro prazer para o homem: ser uma fonte segura de realização pessoal e, ao mesmo tempo, conduzi-lo a um objetivo maior, o bem público.

Daí, para Sêneca, não ter sentido um ensino que não fosse comprometido com a promoção do discípulo e da sociedade. Já no caso da Filosofia, existia, segundo ele, a indissociabilidade entre a teoria e a prática, que pouco ou em nada se relacionava com a sutileza intelectual (Cartas 111, 2).

De acordo com esse raciocínio, a educação deveria estar fundada sobre bases reais, que fossem comuns a todos os homens, indistintamente, e não sobre algo abstrato (VON RINTELEN, 1965). Por esse motivo, Sêneca considerou que o êxito do processo educativo passava pelo que se ensinava e pelo que se assimilava. O que explica a importância que ele deu à elaboração de um currículo, à opção por conteúdos de maior possibilidade formativa, os quais, por extensão, rompessem com as matérias que não levavam a esse propósito.

À medida que pontuou as suas motivações, não se limitou a denunciar a sutileza intelectual como obstáculo à formação humana. A primeira delas dizia respeito às distrações e aos divertimentos, os quais, mesmo que pudessem oferecer algum benefício, não rompiam com a sua condição de banais e inúteis.

Apesar de a sutileza intelectual se apresentar como um dos obstáculos ao processo formativo, este seria facilmente dominado, desde que se estabelecessem objetivos precisos e que se tivesse clareza das dificuldades para a sua realização.

A segunda motivação apontada por Sêneca, a qual ele considerava muito perigosa, tinha origem em uma das tendências inatas do homem: sua curiosidade insaciável, sua busca contínua por aprender, tendo em vista desvendar problemas, uma vez que, em muitos casos, isto levava à especialização.

Esse perigo seria afastado com a adoção de algumas precauções, como, por exemplo: realizar criteriosa seleção das 
matérias e dos conteúdos a serem estudados e estabelecer relações entre as atividades a serem realizadas e a formação pessoal. Sêneca convocou Lucílio a praticar esse exercício: “Corrige os teus costumes [...] tirando de tudo proveito para a tua formação moral, para a repressão das paixões nocivas. Estuda, em suma, não para saber mais, mas para saber melhor" (Cartas 89, 18-23).

$\mathrm{O}$ entendimento da dificuldade de dominar essa tendência natural do homem leva Sêneca à compreensão, e não apenas à crítica dos possíveis deslizes do seu discípulo.

A terceira motivação de Sêneca para combater a sutileza intelectual dizia respeito ao grave fato de esta ser uma opção pessoal ou decorrente de orientações enganadas, situações que comprometiam o aperfeiçoamento humano. "Mas nem sempre o resultado é satisfatório, ou porque os mestres nos ensinam a argumentar e não a viver, ou porque os discípulos procuram os mestres não com a intenção de cultivarem a alma, mas sim de aguçarem o engenho" (Cartas 108, 23).

Essa linha de raciocínio não dispensava nem mesmo a Filosofia, com todo o seu conteúdo formador e transformador, de ser tratada de forma serena e moderada.

Nesse acaso, a denúncia senequiana não se referia à multiplicidade e à inadequação dos conceitos que se propunha a ensinar, mas à direção que a educação tomava quando mestres e discípulos ensinavam e aprendiam matérias e conteúdos que tinham por fim a superficialidade. Deste modo, o cultivo da cultura somente seria concretizado se o objetivo e a intenção fossem formativos, ou seja, se houvesse consonância entre a teoria e a prática.

Nessa reflexão, Sêneca deu a conhecer os ingredientes da receita de uma educação de aparência e ineficaz: o primeiro, aprender por dinheiro; o segundo, desvincular instrução de formação. Nesse engano encontravam-se aqueles que tecnificavam a cultura e a Filosofia e as transformavam em disciplinas específicas desvinculadas da educação moral (GARCÍA GARRIDO, 1969). Contra isso, Sêneca alertou: "Ouve este exemplo do mal que pode fazer a sutileza excessiva, e de como pode ser nociva à verdade" 
(Cartas 88, 43). Em continuidade, conclamou o nosso pensador: "É da maior importância a intenção com que se aborda um assunto" (Cartas 108, 24). Para concluir, afirmou quão enganoso era o estudo com os olhos dos gramáticos (Cartas, 108, 28).

Da mesma forma, tendo em conta a necessidade de se falar mais cuidadosamente do que se vive, Sêneca combateu os que assim ensinavam e os que assim aprendiam, especialmente aqueles que, de uma forma mais grave, transformavam a Filosofia em Filologia (Cartas 108, 24), em vã "verbalidade", em "virtuosismo" intelectual, pouco comprometido com a educação voltada para a perfeição.

A crítica de Sêneca incidia sobre duas situações em que esse processo ocorria: o crescente interesse pela Dialética, que viabilizava as argumentações distorcidas, e o aumento do cepticismo, no qual a dúvida apresentava-se como a única atitude do sábio.

Na perspectiva senequiana, os cépticos eram piores que os dialéticos: "Nem poderei dizer quais são os que mais me irritam, se aqueles que nos não permitem saber nada, se os que nem sequer nos deixam saber que nada sabemos!" (Cartas 88, 46).

Nessa circunstância, a única atitude a ser tomada, segundo ele, era desconsiderar os postulados que desqualificavam o verdadeiro conhecimento.

O que também poderia levar ao ensino verbalista seria a adoção de um grande número de discípulos, uma vez que isto comprometeria a atenção a ser dispensada a cada um, inviabilizando um ensino diferenciado. Por isso, ele proclamou: "Para mim, basta-me que sejam poucos, basta-me que haja só um, basta-me que não haja nenhum" (Cartas 7,11). Na última opção, cabia ao sábio a formação da sua própria pessoa, a autoformação, a qual tinha prioridade. Esse esforço pessoal em busca do aperfeiçoamento poderia se converter num elemento de atração do interesse do discípulo, despertando-lhe a vontade de progredir.

Nesse sentido, era preciso conjugar a luta ascética com as possibilidades, as características e o temperamento da cada discípulo, uma vez que era fácil tornar imposição aquilo que deveria ser apenas um exemplo. Assim, não havia avanço perfectivo sem 
luta e sem esforço. Porém, esse direcionamento deveria ser uma decisão pessoal, e não uma imposição, que poderia levar a interesses alheios à vontade do discípulo, por extensão, a uma formação distorcida.

Para Sêneca, o conhecimento que não estivesse vinculado à sabedoria, que não estivesse comprometido com a operatividade do hábito sapiencial, não era um conhecimento verdadeiramente racional (ALONSO, 1966).

Assim, ele mostrou a necessidade de o discípulo se preparar para enfrentar as distorções provocadas pelos corruptores da cultura. Era preciso conhecê-las, sem, no entanto, exercitá-las.

Não nego que se deva dar uma olhadela ao estudo da dialética, mas uma olhadela apenas, uma saudação, por assim dizer, feita cá de longe e com este único propósito: o de não tomarmos o que não passa de palavreado como se fosse expressão de algum grande e profundo pensamento (Cartas 49,6).

Por outro lado, essa opção implicava uma consciência clara das dificuldades a serem encontradas e do perigo que isso representava para o postulante, especialmente a possibilidade de ele ser cooptado. Entretanto, quando o discípulo dominava as suas paixões e se encaminhava progressivamente a um peculiar saber de tipo soteriológico, não muito extenso ou sutil, que Sêneca qualificou de sabedoria, a regeneração em que consistia a educação não dispensava essa mesma dimensão intelectual (REDONDO e LASPALAS, 1997).

Sêneca não tinha dúvidas: os deuses não haviam agraciado o homem com a sabedoria; o acesso aos domínios desse bem requisitava esforço e dedicação pessoal, até mesmo por parte dos privilegiados pela natureza.

A partir dessa formulação, novas questões se colocam: podese pensar que Sêneca advogou a eliminação, no processo formativo, do que não estivesse vinculado à racionalidade? A educação, para ele, quando respaldada pela razão, viabilizava obstáculos aos impulsos irracionais? 
As respostas foram oferecidas por Sêneca da forma seguinte: “A educação exige o máximo de diligencia, para que seja aproveitada ao máximo, fácil é ajustá-la aos espíritos ternos, com dificuldade se aproximam dos vícios que crescem em nós" (SÉNECA, De la cólera, II, 18, 2, 2000).

Fica evidente, assim, que, para ele, o processo educativo também recebia a influência das múltiplas manifestações da "têmpera" humana, uma vez que a entendia como um conjunto harmonioso de caráter notadamente corporal, portanto, inteiramente ligado à natureza física do homem.

Tanto a têmpera quanto a racionalidade estavam relacionadas à natureza humana, e a educação não pode pretender a sua eliminação da sua esfera de ação. “Modificar a natureza certamente é difícil, como não é fácil alterar os elementos já constituídos nos homens" (SÉNECA, De la cólera, II, 20, 2, 2000).

Em face disso, no processo educativo, quando se acompanhava a natureza, não se poderia negar esse aspecto, uma vez que ele era inerente à natureza de cada homem em particular. Dever-se-ia, portanto, ordenar adequadamente os dois aspectos do homem, submetendo o inferior ao superior, a sua alma racional.

Evidencia-se, assim, que a preocupação senequiana era apontar o caminho para "seguir a natureza". Disso decorre a abrangência da sua reflexão, que diz respeito ao homem em sua totalidade, corpo e alma: "O nosso objectivo é, primacialmente, viver de acordo com a natureza. Ora é antinatural torturar o próprio corpo" (Cartas, 5, 4).

Fica explícito em Sêneca que o processo educativo não pode abdicar e/ou desconhecer a materialidade humana como objeto de sua ação, mesmo que alocada em segundo plano: "Cultiva, portanto, em primeiro lugar a saúde da alma, e só em segundo lugar a do corpo" (Cartas 15, 2), em vista de sua tendência natural de submeter o homem.

Revestido desse entendimento, o processo educativo devia possibilitar ao homem os instrumentos necessários para que rompesse com a condição a que estava submetido e buscasse o bem maior para o qual nasceu: a felicidade. Como resultado desta 
vida feliz, brota uma tranqüilidade plena, uma verdadeira liberdade.

Em suma, é esse o entendimento senequiano, tanto em relação à possibilidade de a educação encaminhar o homem para a perfeição quanto à necessidade dela para que ele atinja essa dádiva divina. Segundo ele, esse é o objetivo e a meta do homem preocupado em promover a sua racionalidade e, por meio dela e de seu exemplo, chegar à humanidade.

Outro traço da educação, conforme concebida por Sêneca, é sua permanência: a sabedoria não se esgota, nunca é tarde para aprender.

Esse princípio da educação permanente não pode ser traduzido como obrigação de permanecer para sempre na escola ou como a possibilidade de nunca se obterem os resultados contemplados nos objetivos traçados para se atingir a perfeição e, assim, de se estacionar em uma infância moral e espiritual. O oposto aconteceria se a dinâmica fosse diferenciada e bem orientada.

Este entendimento levou Sêneca a exortar Lucílio a se dedicar aos estudos enquanto ainda jovem, para que não se repetisse nele a sua história: aprender quando velho. $\mathrm{O}$ aprendido na juventude podia ser aperfeiçoado na velhice (Cartas 88,35).

Nisso consiste o segundo motivo para que ele considerasse a educação como algo permanente: além de a sabedoria não se esgotar, ela não era obtida plenamente (REDONDO e LASPALAS, 1997). Por isso, ele conclamou Lucílio a seguir o caminho em sua direção, tendo em vista uma vida digna.

No fundamental, para Sêneca, nada poderia substituir a educação dirigida pelo próprio discípulo, o que o levou a sentenciar: “A virtude não se conquista por procuração" (Cartas 94, 5). Para além, concluiu: "Um espírito virtuoso não é coisa que se peça emprestado ou se possa comprar. E mesmo que existisse à venda, receio bem que não encontrasse comprador. O vício, esse todos os dias tem quem o adquira" (Cartas 94, 8).

Desta forma, Sêneca concebia a virtude como a disposição para se atingir o aperfeiçoamento total da parte racional da alma. Por meio da razão ocorria o aperfeiçoamento das ações livres, de forma 
que, por meio da virtude, o homem se inseria na harmonia da natureza (LEÓN SANZ, 1997).

Nesse sentido, a virtude era o resultado da busca pessoal do conhecimento filosófico e este era um fator de transformação que não poderia ser aprendido sem o consentimento do discípulo.

Sêneca punha em destaque a capacidade do homem de se autodirigir e, sustentado pela moral e pela razão, reconhecer-se como parte integrante de um todo harmonioso (ULLMANN, 1996).

Daí a necessidade do exercício da vontade na busca do processo autoformativo. "Aquilo que pode fazer de ti um homem de bem existe dentro de ti. Para seres um homem de bem só precisas de uma coisa: a vontade" (Cartas 80,4).

Essa atitude assumia maior dimensão quando o objetivo era o progresso moral, independentemente dos problemas e das dificuldades a serem enfrentadas ao longo da sua realização. " [...] E então? - dirás. Tem sido essa a minha vontade" (Cartas 34, 3).

Respaldada pela razão, a vontade ganha força decisória, porque distingue o moral do imoral, indica o caminho do bem e desvia do mal, numa dinâmica facilitadora da felicidade. Em Sêneca, o fato de o homem trazer consigo, ao nascer, as condições para o bem não o dispensa da sua vontade para desenvolvê-lo (OLIVEIRA, 1998) e efetivá-lo, especialmente quando se tem em conta que se trata de uma determinação da natureza. "Só há uma solução, portanto: ser firme e avançar, sem descanso, mas grande parte do progresso consiste na vontade de progredir" (Cartas 71, 36).

Ao aceitar o destino, a vontade contribui para a harmonia universal; o homem, como parte integrante do universo, é favorecido por essa harmonia, uma vez que participa da ordenação cósmica.

O esforço do homem para chegar a esse entendimento permite que ele se aproxime da divindade e do seu próprio querer, o que, para Sêneca, significa a união entre a vontade humana e a vontade divina (OLIVEIRA, 1998). Esta relação não permite separação, pois a harmonia universal está a ela vinculada. 


\section{O sujeito da Educação}

Em face das muitas dificuldades que particularizam a escalada rumo à perfeição, pode-se pensar que, para Sêneca, o seu acesso estava reservado a homens privilegiados. Existiria uma tendência de alguns homens a obter esse ideal ou, na dinâmica oposta, alguns naturalmente incapazes para atingir esse bem.

É certo que, em suas análises, Sêneca reconheceu a existência de almas nobres, com características especiais e com excelente disposição. No entanto, ele próprio considerava isso insuficiente para se encontrar a própria perfeição, uma vez que poucos a realizavam.

Isto sugere a existência de uma predisposição para enfrentar obstáculos, particularmente os referentes ao próprio homem, como a pouco ajuda mútua entre eles e o fato de uns não serem exemplo para os outros. Para Sêneca, a ajuda mútua é uma exigência imposta pela natureza, o seu mais imediato mandamento, e, para além dela, reflete-se no âmbito racional humano (VON RINTELEN, 1965). A não-realização desse projeto afetava diretamente a concretização da perfeição: "são uns para outros maus exemplos: todo aquele que segue o que está à frente, mesmo quando este tomou equivocadamente o caminho, não terá desculpas, uma vez que extraviou a direção de todos" (SÉNECA, De la Cólera, II, 10, 3, 2000).

Por esse motivo, o desejo inicial de quem almeja chegar à conquista de si mesmo não pode ser irreflexivo, pelo contrário, deve ser capitaneado pela reflexão, para não ser atrapalhado e atropelado. Esses eram os motivos pelos quais muitos daqueles que investem na busca da perfeição, sem esperança e intimidados diante do fracasso, abandonam os seus projetos.

Destarte, não é suficiente a vontade inicial; isto não deixa de ser bom, mas faz-se necessária uma vigilância constante das dificuldades que se colocam no processo, e Sêneca alertava seu discípulo para elas: "O laço mais forte a prender-te à prática da virtude é este: comprometeste-te a ser um homem de bem, confirmaste-o por um juramento. Se te disserem que se trata de uma militância ligeira e fácil estão troçando de ti" (Cartas 37,1).

Deve-se estar ciente da necessidade da luta contra o desânimo 
que, cedo ou tarde, se fará presente. A arma contra esse inimigo implacável é dotar-se de um inquebrantável espírito de perseverança, aliado a uma efetiva autoconfiança e motivado pela certeza de que a sua natureza tem o dom da perfeição.

Para a realização do supremo bem, cabe ao homem o encontro consigo mesmo. Essa condição é conquistada mediante um processo de interiorização, de um permanente enfrentar-se com as próprias limitações, com o que nelas se apresenta como antinatural: uma ascese purificadora. O bem supremo configura-se no juízo e nas atitudes de uma alma perfeita, ou seja, quando já se consumou a sua caminhada (USCATESCU, 1965).

Estas considerações apontam para duas questões significativas. A primeira diz respeito ao caráter de urgência do seu programa educativo, justificado pelo estado de enfermidade que ele observava na humanidade. A segunda refere-se aos destinados a serem beneficiados por esse programa, os quais deveriam se converter em multiplicadores e em exemplo de homens que respondiam às necessidades da sua sociedade e do seu tempo.

Com base nessa premissa, Sêneca procurou mostrar aos seus discípulos a importância do critério de seleção, ou seja, de buscar, antes de tudo, aqueles que se apresentassem mais propensos ao ideal de conquistas, pois não se podia esquecer que o processo formativo demandava tempo e dedicação. Por isso, não se podia considerar como discípulo um simples conhecido ou um amigo, mas sim, sem o atropelamento da pressa, aquele que tivesse as condições necessárias para sê-lo. Caso o mestre procedesse de outro modo, demonstraria falta de respeito para com a natureza daquele que se pretendia formar.

O mesmo erro também cometeria o mestre que exercesse uma atitude autoritária com o discípulo, justificando-a pela necessidade da rapidez na realização dos objetivos traçados. Neste caso desconhecia-se que o acesso à perfeição pressupõe esforço pessoal e que o mestre não era nada mais que um guia nesse processo. Isso não significava que se devia dar ao discípulo liberdade plena, porque, mais cedo ou mais tarde, ele seria afetado pelas inúmeras dificuldades interpostas na caminhada. 
Não obstante, sob dadas circunstâncias transitórias, Sêneca aceitava que se empregasse certa força coercitiva: "A certos doentes basta que se lhes indique os remédios; outros têm de ser obrigados a tomá-los!" (Cartas 27, 9). Desse modo, a formação apresentava graus diferenciados de ação: a ação de guia e a de ajuda enérgica, que podia chegar à coação. Nessas duas situações, o mestre estava diante de homens que não bastavam a si mesmos, porém, entre esses podiam ser identificados aqueles com mais capacidade do que outros. Assim se explica que o programa educativo de Sêneca esteja voltado especialmente aos primeiros, que, convenientemente descobertos e selecionados, dariam as condições para a realização de um trabalho educativo mais efetivo e eficiente: "Se bem observarmos, os mais pequenos pormenores podem ser elucidativos, em qualquer situação. Por exemplo, o mínimo gesto pode servir de indício da moralidade das pessoas" (Cartas 52,12). Efetuada a seleção, fazia-se necessário, por parte do mestre, adaptar-se às características pessoais de quem tinha em vista orientar, pois Sêneca acreditava que "certos espíritos são abertos e receptivos, outros precisam, como sói dizer-se, de ser modelados à mão, de gastarem nas fundações o melhor do seu esforço" (Cartas $52,6)$. O mestre não podia ter dúvidas: mesmo que a sua missão fosse mais difícil, o segundo grupo merecia especial atenção e reconhecimento pelo esforço, dedicação e persistência em alcançar os seus objetivos formadores.

Para Sêneca, os melhores discípulos buscavam a sabedoria com absoluta pureza de intenção. Não se podia duvidar daqueles que sob pressão poderiam ser levados para o caminho do bem e que necessitavam não apenas de um guia, mas de alguém que os amparasse com palavras e ações, e até mesmo que os forçasse a prosseguir nessa direção (Cartas 52,4).

Esse procedimento formativo defendido por Sêneca distanciava-se de uma educação de massa e ao mesmo tempo implicava um tratamento individualizado (GARCÍA GARRIDO, 1969). Mesmo com essa postura, Sêneca não negou que a perfeição era um bem acessível a todos os homens.

Isto explica o seu entendimento de que as possibilidades para 
atingi-la eram uma dádiva dos deuses a todos os homens, indistintamente de condições sociais, políticas e econômicas, o que não dispensava o esforço pessoal de cada um para realizar o processo educativo. Assim, nas palavras de Sêneca, o homem deveria romper com os vícios e as paixões e retornar limpo ao seu lugar de origem na natureza (Cartas 94, 55-56 e 68).

Com base nessas reflexões, Sêneca se contrapôs ao Mestre do Jardim: "Epicuro diz que todos estamos, ao abandonar a vida, no mesmo ponto em que estávamos ao nascer". De forma diferente, Sêneca afirmou: "Se somos piores ao morrer do que ao nascer, o defeito é nosso, não da natureza. Esta teria o direito a queixar-se de nós: "'Que é isto: Eu gerei-vos sem ambições, sem medos, sem superstições, sem maldade, sem qualquer outro vício do mesmo jaez. Saí, portanto, tal como entrastes!"” (Cartas 22, 15).

Motivo por que, para Sêneca, quando o homem, em suas ações, entrava em dissonância com a natureza, levada pelos vícios e paixões, e chegava ao estágio da irrecuperabilidade, a responsabilidade era inteiramente sua e daqueles que o cercavam no seu meio social.

No entanto, Sêneca hipotecava em favor do homem a possibilidade de reverter o caso, desde que voltasse a um exercício responsável, contínuo e persistente em busca da perfeição.

Por serem iguais, todos os homens eram convidados a buscar a sabedoria. Este bem não era exclusivamente de homem algum, assim como ninguém chegava aos limites da perfeição.

Não havendo sábios definitivamente distintos uns dos outros, cada homem estava qualificado a atingir determinado grau de sabedoria, o que exigia uma dose de humildade para aceitar a possibilidade de não alcançá-la em seu estado pleno e para lutar e se aproximar cada vez mais do seu objetivo; no pior dos casos, lutar para não se afastar do que estava traçado (GARCÍA BORRÓN, 1966).

As reflexões senequianas, que levaram à sua antropologia pedagógica, defendiam que o homem tinha sido dotado pela natureza das condições necessárias para se libertar da escravidão a que estava submetido. $\mathrm{O}$ resultado disso era a sua capacidade 
para se educar, para buscar a perfeição, independentemente da condição social, uma vez que suas origens eram vinculadas às divindades.

Nesta perspectiva, o sentido de perfeição, para Sêneca, era um atributo essencial da alma, conforme está explícito em uma das suas célebres sentenças: "Uma alma assim tanto pode encontrarse num cavaleiro romano, como num liberto, como num escravo" (Cartas 31, 11).

Essa preocupação com a alma como fator que promovia a semelhança e a aproximação entre os homens, num caráter universalista, deu a Sêneca as bases para defender sua posição de que a educação era um bem que deveria ser extensivo a todos: nem mesmo escravos e executores de trabalhos servis poderiam ser excluídos dela.

A partir dessa orientação, a alma requisitava que a educação transpusesse as barreiras sociais que separavam os homens, convertendo-os em um corpo único e universalizado.

Esse posicionamento de Sêneca pode ser entendido como pouco comum naquele momento histórico, particularmente porque se tratava de uma sociedade que negava o trabalho mecânico e desconsiderava os setores sociais inferiorizados, responsáveis pela produção da vida.

Mesmo não comportando uma dimensão revolucionária, essa discussão não deixou de ser uma contribuição da Antiguidade ao homem contemporâneo.

Também fundamentado no estoicismo, Sêneca afirmou que a natureza humana, o ser do homem, trilhava etapas ou graus, em seu processo formativo, em busca da sabedoria.

\section{As etapas do conhecimento}

Nesta discussão, Sêneca situava no primeiro grau os homens que, mesmo não tendo atingido sabedoria, encontravam-se próximos desse bem maior: aqueles que já tinham se libertado das paixões e dos vícios e angariado conhecimentos significativos para esta conquista, o que, no entanto, não os capacitava para dar 
seqüência à sua caminhada com confiança plena, ou seja, eles não estavam prontos para o exercício do bem supremo. Em contrapartida, embora não tivessem ainda uma noção clara da sua própria pessoa, em síntese, "não soubessem que sabiam", o retorno ao antigo estado de escravidão já não era uma ameaça, não era possível um retrocesso.

Segundo o pensador, muitos outros filósofos estóicos incluíam nesta classe os homens que já haviam se libertado das doenças da alma, mas ainda estavam presos a paixões e, por isso, ainda não estavam seguros. Concluindo, os homens mais dedicados aos conhecimentos já tinham se libertado das doenças da alma, mas, por ainda estarem próximos da perfeição, estavam também sujeitos à ação das paixões (Cartas 75, 9-12).

Este estágio pressupõe o encontro com a Filosofia, que levava ao amor à sabedoria.

No grau intermediário, Sêneca situava aqueles que, embora tivessem conseguido se libertar das principais enfermidades da alma e das paixões, ainda não tinham alcançado o estado definitivo e pleno de tranqüilidade e estavam sujeitos a recaídas.

Neles se observava um significativo aprimoramento do exercício intelectual e contemplativo, regado, segundo Sêneca, por "[...] uma favorável disposição natural e de uma intensa e assídua aplicação ao estudo" (Cartas 75,13).

No terceiro grau, ele identificava os homens que tinham se libertado de um número considerável de vícios, mas não da totalidade deles. Libertaram-se da prática da avareza, mas não da ação da ira; o prazer já não os provocava, o que não acontecia com o espírito de ambição; estavam imunes dos desejos, mas não do temor: a morte já não os amedrontava, mas temiam a dor física (Cartas 75,14).

A referência para esta categoria era a maturidade contemplativa, própria daqueles que tinham avançado nos estudos.

No desenvolvimento deste pensamento, Sêneca foi cauteloso, na medida em que não identificou outros graus de conhecimento, deixando espaço aberto para lutas, buscas e conquistas em nível pessoal. Em particular, aconselhava que o homem sóbrio, ao 
alcançar um dos seus objetivos, não agisse como quem já tivesse atingido o objetivo definitivo. Por esse motivo, não se sentiria constrangido em se incluir, ou pelo menos almejar, o terceiro grau.

A possibilidade de novas conquistas, como apontava Sêneca, indica quão insensata e pretensiosa era a postura daqueles que, por excesso de confiança, revestiam-se de intranqüilidade por não contemplarem com clareza o caminho da perfeição e, desta forma, mostravam que, neles, a sabedoria ainda não se fazia presente em nível suficiente. A postura do sábio, ao contrário, era de quem, pautado na tranqüilidade, na persistência, na paciência e na certeza do bem a conquistar, sabia quais os caminhos a seguir, numa atitude que rompia com a auto-suficiência, condenada por Sêneca (VON RINTELEN, 1965). Não se quer dizer com isto que Sêneca induzia a uma atitude passiva e conformista: para ele, fazia parte do homem dedicado a ser sábio, querer buscar sempre mais o conhecimento e a perfeição.

Estas considerações eram dirigidas especialmente aos neófitos da sabedoria, diante da excessiva ambição de todos os iniciantes e do fato de que a morosidade na obtenção da sabedoria poderia oportunizar um desânimo irreversível.

Segundo Sêneca, as baixas neste processo poderiam ser em grande parte evitadas com o acompanhamento de um guia conhecedor do difícil caminho a ser seguido, conforme orientou o seu irmão Novato da necessidade de se escolher um perito, conhecedor profundo do caminho a ser seguido, ante as dificuldades que particularizavam esses itinerários:

\section{$O$ recurso de um modelo}

Para Sêneca, o modelo levaria ao conhecimento das pegadas indicativas da direção a ser tomada, ajudaria a identificar o momento de avançar e o momento de parar (PRADO, 1946, p. 47), de modo a se atingir o objetivo proposto, a realização do bem maior, a perfeição. Ou seja, o recurso de um modelo possibilitava segurança para percorrer esse caminho consciente e acertadamente: "Devemos deixar-nos guiar enquanto ainda 
estamos aprendendo a guiar-nos por nós mesmos. Um tal auxílio deve ser dado ao nosso espírito enquanto aprende a guiar-se por um modelo [...]" (Cartas 94, 50-51).

De acordo com Sêneca, a História é generosa nesse sentido, e oferece à humanidade a memória de homens cujas existências são verdadeiros exemplos e que estão sempre à disposição para atender aos que a eles recorrem (Sobre a brevidade da vida XIV, 1-2-5).

Com isto, Sêneca revela a perenidade dos valores espirituais e mostra que todos os homens de boa vontade têm condições de viajar para fora do seu tempo, aprender com as grandes personalidades de qualquer época, entrar em contato com a sociedade universal dos espíritos e pensar e discutir com eles as coisas eternas. Este espetáculo oferecido pela História não chamava a atenção apenas daqueles preocupados com as ações externas. Para o homem envolvido com a contemplação, a História não se limitava ao vai-e-vem das aparências; sob os acontecimentos sucessivos e acidentais se descobria o permanente e o substancial, o que havia de eterno no homem, no seu pensamento e no ser de cada um (MOREAU, 1966).

Esta volta ao passado para dialogar com aqueles que, em Sêneca, foram os melhores espíritos, tinha a propriedade de contribuir para a plenitude da vida. Esse era o verdadeiro caminho da sabedoria, da dimensão da humanitas no ensino de Sêneca.

Apesar deste conteúdo fecundo encontrado nos grandes homens, Sêneca recomendava que, quando o discípulo se sentisse seguro em relação aos seus propósitos e às suas conquistas, deveria se afastar do seu guia, por já estar em condição de dar continuidade à sua caminhada evolutiva rumo à perfeição.

\section{Os fatores do aperfeiçoamento humano}

Em Sêneca, a perfeição, por ser uma possibilidade facultada ao homem, somente acontecia por meio de um processo educativo que tinha em vista a realização da natureza racional do homem. A perfeição era identificada como ideal, como meta a ser atingida: mesmo que a natureza humana fosse apresentada de forma 
normativa, também era concebida como força que plasmava o homem no seu ser, tanto na esfera racional como na temperamental. Esta condição própria da natureza deveria ser conquistada no dia-a-dia, com base em suas próprias e graduais conquistas racionais.

Nesta caminhada, era necessário preservar o discípulo de ambientes inadequados e nocivos, bem como realizar uma paciente eliminação de hábitos não compatíveis com a perfeição. Para isto, bastava que o homem assentisse, com sinceridade de propósitos, na manifestação de suas potencialidades naturais, ou seja, na realização do processo formativo.

Nessa direção, o principal objetivo do mestre e do discípulo deveria ser a criação de condições que favorecessem o dinamismo perfectivo inato no homem. É com esse sentido que Sêneca aconselha Lucílio: “[...] com todo o empenho que nunca deixes esmorecer ou esfriar o ímpeto que te vai na alma. Conserva-o, dálhe forma, de modo a que esse ímpeto de hoje se torne configuração permanente da tua alma" (Cartas 16, 6).

Além desse conselho, ele mostra a importância da ação do homem para favorecer o despertar dos dons com que a natureza o agraciou.

Esta, para ele, não era uma atividade difícil de ser realizada, não era um obstáculo a ser transposto, principalmente quando se era jovem. A única exigência era criar as condições para o seu desabrochar.

Nem por isto, em Sêneca, a condição de sábio era exclusividade do ancião. Um jovem, mesmo em fase de formação, mas com vigor na busca da perfeição, tinha tanto ou até mais mérito do que um homem velho alquebrado pela luta contra seus vícios recorrentes. Neste caso, por suas conquistas pessoais, pode-se admitir que esse jovem tenha acesso à perfeição, à sabedoria (GARCÍA GARRIDO, 1969).

No geral, no pensamento senequiano, o homem havia recebido da natureza o talento para o essencial, ou seja, para a formação moral, o que, por seu turno, implicava o esforço pessoal para cada um se educar. Essa exigência era também extensiva aos mais 
agraciados pela natureza, uma vez que o processo formativo não se realizaria ao acaso ou pela ação externa ao homem: "Muitas vezes um bom material permanece inutilizado por falta de quem o trabalhe" (Cartas 47, 16). "Ninguém é bom por obra do acaso; a virtude aprende-se" (Cartas, 123, 16); por outro lado, “Uma vez aprendidos, os bens da sabedoria permanecem para sempre na nossa posse" (Cartas 50, 8).

O modo pelo qual Sêneca entende a educação tem como objetivo destacar que nesse processo o fundamental era modelar o caráter e a personalidade. Isto pressupunha exigências e dificuldades: poucos o realizavam em sua plenitude. Daí a necessidade de se investir no esforço pessoal para se educar e aceitar, com humildade, a ajuda exterior: "Lutemos, portanto, sem temer pedir o auxílio alheio" (Cartas 52, 2-3-6-7).

Um exemplo da ajuda prestada pelo mestre, assim como daquela possibilitada pelo ambiente, reside naquilo que Sêneca denominou de preceitos, os quais favoreciam, em grande medida, o surgimento de princípios ou convicções no discípulo. Esses preceitos refletiam a grande influência exercida pelo meio para implantar princípios sem que o discípulo se esforçasse por entender e praticar a sabedoria.

\section{Fins e objetivos da Educação}

Numa perspectiva teleológica, a felicidade apresenta-se no pensamento senequiano como o fim da vida humana e, por extensão, como o fim da educação. No entanto, é necessário considerar que a felicidade é resultado direto da virtude: apenas os bons, os que investem na virtude em alto grau de perfeição, são felizes. A condição para se alcançar a felicidade é viver de acordo com a natureza: somente vivem em retidão de vida os que adentram os domínios da sabedoria e, por intermédio dela e na sua proporção, atingem a perfeição, a virtude e a felicidade. Felicidade, virtude, perfeição, retidão de vida e sabedoria são os cinco elementos fundamentais e indissociáveis da educação em seu fim último: a formação do homem ideal, o sábio. 
A esse fim último do processo formativo senequiano, no entanto, é inerente também a dificuldade de sua realização, na medida em que se trata de um ideal que, segundo Sêneca, é alcançado, de tempos em tempos, por alguns homens dotados de traços de excepcionalidade: "Olha que um homem de bem não é coisa que surja assim tão depressa! E sabes o que eu entendo aqui por 'homem de bem'? Apenas o de segunda categoria, porque o de primeira é como a fênix, que só aparece uma em quinhentos anos" (Cartas 42, 1-2).

Mesmo com as dificuldades que se colocam no processo formativo, Sêneca acredita que o ideal de sábio pode ser alcançado. Entretanto, para inviabilizar possíveis presunções, Sêneca prefere apresentar o sábio não como aquele que atingiu o objetivo definitivo, numa perspectiva idealista, conforme proposto pelo estoicismo (GARCÍA BORRÓN, 1966), mas como um homem inteiramente ligado, plenamente envolvido, perfeitamente engajado no caminho que um dia escolheu para trilhar. O sábio, ainda que assoberbado de saber, continua no seu caminho, sempre em busca de progresso, o que o torna perfeito. Isto explica que o ápice da perfeição seja algo que ele tem sempre em mente, olhando sempre de baixo para cima, nunca de cima para baixo. Também lhe causa admiração a sabedoria em outros, particularmente naqueles que foram laureados com a última dádiva da sabedoria, uma morte segundo os cânones estóicos (GARCÍA GARRIDO, 1969). Sêneca propõe também a superação da auto-suficiência do sábio estóico.

Mesmo que se atingisse o estágio máximo do conhecimento, o processo formativo não estaria consumado, uma vez que, com essa conquista, abrir-se-iam novas possibilidades para o que seria considerado como perfeição, o que, por seu turno, implicaria também a possibilidade de novos obstáculos.

No processo de aperfeiçoamento, que, em última instância, leva à aquisição da virtude e, com ela, à conquista da felicidade, assumem papel decisivo a liberdade e a filosofia, elementos que formam a medula da ordem moral. A essência de uma conduta moral tem por base a liberdade e o conhecimento: sem o 
conhecimento não se conquista a liberdade e sem liberdade não se alcança a moralidade. Portanto, não se tratava da liberdade garantida pelo direito público, mas da liberdade como dádiva do direito natural, ou seja, da liberdade, da independência, da autonomia advinda do interior, libertadora do medo da morte, da pobreza, dos vícios e de tudo o que se origina dos desejos do corpo. Não se trata, também, de uma liberdade de caráter psicológico, subjetiva ou relacionada às posses e à necessidade de atender às suas exigências. A liberdade com que Sêneca brinda a humanidade somente a Filosofia pode oferecer (SANGALLI, 1998). Manifestase, assim, a exigência de uma luta ascética contra as paixões, cujo caráter violento de que, com freqüência, se revestem dificulta a aquisição da sabedoria: "Nós, estóicos, não podemos ser desmoralizados! 'De que modo então - perguntas tu - conseguirei libertar-me?' Tu não podes escapar ao inevitável, mas podes vencêlo! Abre-se caminho à força (Cartas, 37,3)".

Para Sêneca, a liberdade poderia abrir fendas em um mundo em que as necessidades eram duramente colocadas na ordem do dia. Ao não se submeter à ação da fortuna e saber aceitar as leis impostas pela natureza, das quais a mais radical e cruel, para o nosso pensador, era a degradação a que estava submetida a condição humana: homo servus, homo aeger, homo victus (homem escravo, homem doente, homem vencido), o homem teria condições de ser plenamente livre.

A libertação moral constituía, para Sêneca, o maior prêmio da formação da unitas generis humani (unidade do gênero humano). Este processo deveria ser traçado para despertar no individuo o seu impulso para a sociedade.

O restabelecimento, em parte, da saúde da alma, a conquista da liberdade interior o senhorio e a posse de si mesmo são précondições para qualquer tipo de formação filosófica. Na empreitada de libertação em que consiste a educação, delineia-se, em seus primeiros momentos, uma expressiva e singular dificuldade a ser superada pelo discípulo.

Em face disso, a ação do discípulo deve ser direta e firme contra os vícios que cerceiam a liberdade. Esse impulso do processo 
libertador repousa na consciência do pecado, numa espécie de ignorância ética, pois quem não tem consciência do pecado não está em condições ou não está capacitado para a correção pessoal. A consciência possibilita o reconhecimento da culpa, assim como é condição da regeneração humana. Esse é o motivo de Sêneca ter sentenciado: o princípio da saúde é a consciência da culpa.

Esse posicionamento de Sêneca - vale lembrar - pode ser o equivalente ético da "douta ignorância" socrática, bem como o processo que levava à conquista do saber, do vir sapiens (homem sábio) e da consciência dos próprios limites convertia-se em impulso para a regeneração da virtude, do vir bonus (homem de bem), e a consciência do próprio pecado. "Para seres um homem de bem só precisas de uma coisa: a vontade" (Cartas 80,4). "Esta questão está dependente da vontade, e por isso uma grande parte de bondade consiste em querermos ser bons" (Cartas 72, 3).

Constatada essa situação, faz-se necessário desencadear uma ação recuperadora: “[...] se há nos olhos alguma impureza que impeça a visão, é preciso eliminá-la, admito que alguém nesta situação não careça de preceitos para ver, mas sim de um remédio que lhe limpe os olhos e remova o obstáculo a uma visão perfeita" (Cartas 94,18).

Rigorosamente, pelo entendimento senequiano, ninguém chegava ao domínio da virtude simplesmente porque se sentisse atraído por ela; pelo contrário, fazia-se necessário ser impelido, projetado para sua esfera. Esse é o motivo da sua exortação: “A virtude autêntica, porém, só é possível a uma alma instruída, cultivada, uma alma que atingiu o mais alto nível através de uma exercitação" (Cartas 90, 46).

Essas orientações balizam algumas questões significativas. A primeira é a alma instruída: ele destacava a necessidade primária da instrução, do ensino e da aprendizagem intelectual; a segunda, a alma cultivada: ele evocava um arcabouço de conhecimento orientado; a terceira, a exercitação, que ele referia ao esforço despendido pelo homem para alcançar a virtude, o que precisava de um guia.

Pelo que se pode observar, Sêneca, mesmo destacando a 
existência de homens de primeira classe, não tem grande apreço por eles. Eis como ele conclui a sua reflexão: “Nós não pertencemos aos espíritos da primeira escala, e devemos dar-nos por felizes se formos aceitos entre os de segunda" (Cartas 52,3).

Neste caso, Sêneca incluía-se, juntamente com Lucílio e tantos outros pares, entre os esforçados e conscientes das suas próprias limitações - os que constituíam a segunda classe. Ele punha às claras que, no seu projeto pedagógico, a sua filosofia tinha sido pensada para essa categoria de homens que, segundo seu juízo, eram seletos, com notória capacidade.

Nessa discussão, Sêneca não se esqueceu da existência de uma terceira classe de homens (GARCÍA GARRIDO, 1969), que também merecia atenção, uma vez que essa posição era acessível a todos os homens.

Na concretização dessa operação, conforme já foi mencionado, papel fundamental era atribuído à liberdade, a qual tinha no corpo humano o seu principal campo de batalha. Para o pensador, o processo libertador consistia, pelo menos em parte, em se desvencilhar das asperezas do corpo, no qual a alma estava enclausurada como num triste e sombrio domicílio, tornando-se a filosofia um meio libertador.

Em razão de a alma se encontrar tiranizada e presa no corpo, ela perde a liberdade, cabendo à educação, no seu aspecto corporal, também responsável pelo processo formativo, contribuir para a sua libertação, respaldada numa orientação básica, ascética e sensível. Por esse motivo, Sêneca ponderava: “O estômago não se contenta com sentenças: reclama, e exige ser satisfeito. Não é, todavia, um credor muito exigente: ir-se-á embora com pouco desde que lhe dês apenas o que deves, e não tudo quanto podes" (Cartas 21,11).

Vale considerar que mesmo este fundo sóbrio com que Sêneca marcou a existência humana não afetou o seu otimismo pedagógico, cujo fim era não apenas recuperar as antigas virtudes romanas, mas, principalmente, devolver ao homem a consciência da sua condição de homem, para que pudesse se posicionar de maneira efetiva diante de seu destino, de sua vida e de sua própria 
morte (USCATESCU, 1965). Essa consciência e essa atitude eram cada vez mais raras na sociedade romana de seu tempo, bombardeada e afetada por uma inversão de valores que negava a moral e a ética pregadas e consagradas pela romanidade.

$\mathrm{Na}$ revisão desse quadro, o fundamental era investir na formação do homem e levá-lo a responder às necessidades que se colocavam, o que passava em primeira instância por uma organização, um planejamento do ensino, ou seja, por viabilizar as condições para se conformar este homem ideal.

Esta preocupação com a formação humana, assumida por Sêneca, ao longo da sua vida, como missão pedagógica da qual nunca se distanciou, ganhou expressão até mesmo na sua morte momento, segundo acreditava, da libertação humana, motivo de tê-la convertida num ato pedagógico pleno de intenção educativa.

As suas reflexões e as sua práticas pedagógicas transformaram-no em uma das vozes romanas mais importantes e significativas em matéria de educação. Isso fica explícito na sua ressonância ainda na Antiguidade, quando exerceu notável influência nos chamados Padres da Igreja, a exemplo de Clemente de Alexandria, Tertuliano, Santo Ambrósio e Santo Agostinho; ao despertar, na Medievalidade, o interesse de pensadores como Lactâncio, Martins de Braga, Tomás de Kempis e Santo Tomás de Aquino, entre tantos outros; ou, ao chegar à Modernidade e à Contemporaneidade, despertando a simpatia de Montaigne, Descartes, Leibniz, Kant e Nietzsche.

Essa permanência na História é significativa para justificar um estudo sobre o pensamento de Sêneca que, num processo dinâmico e criador, invadiu outras épocas distantes da sua e evidenciou a validade de seu modelo pedagógico, fundado na ética e na moral, princípios esses que apresentam traços de semelhanças em todos os tempos, lugares e culturas. O que é provável, isto também foi possível graças à solução prática que apontou para os problemas existenciais, em vista do seu entendimento da natureza humana e da determinação dos valores humanos. 


\section{Referências}

ALONSO, Adolfo Munõz. El Conocimiento em Séneca. In: ESTUDOS SOBRE SÉNECA. Anais... Madrid: Instituto Luis Vives de Filosofia e Sociedade Española de Filosofia, 1966.

CAMBI, Franco. História da Pedagogia. Assis: Editora da Unesp, 1999.

GARCÍA BORRÓN. El senequiano español. In: ESTUDIOS SOBRE SÉNECA. Anais... Madrid: Instituto Luis Vives de Filosofia e Sociedade Española de Filosofia, 1996.

GARCÍA GARRIDO, José Luis. La Filosofia de la educación de Lucio Anneo Séneca. Madrid: Editorial Magisterio Español, 1969.

LEÓN SANZ, Isabel Maria. Sêneca (H. 4 a .C - 65 d.C). Madrid: Educacionales del Oro, 1997.

MOREAU, Tomás. Providencia y destino en Séneca. In: ESTUDIOS SOBRE SÉNECA. Anais... Madrid: Instituto Luis Vives de Filosofia e Sociedade Espanõla de Filosofia, 1966.

OLIVEIRA, Luizir de. Sêneca, a vida na obra (uma introdução à noção de vontade nas epístolas a Lucílio). 1998. Dissertação (Mestrado em Filosofia) - Programa de Estudos Pós-Graduados em Filosofia, Pontifícia Universidade Católica de São Paulo, São Paulo, 1998.

PRADO, Anna Lia Amaral de. Apontamentos para um estudo sobre a moral de Sêneca nas Epistolae ad Luciliun. Anuário da Faculdade de Filosofia do Instituto "Sedes Sapientiae". São Paulo, p. 159-170, 1946-47.

REDONDO, Emilio; LASPALAS, Javier. História de la educación. Madrid: Dykinson, 1997. 
SANGALLI, Idalgo José. O fim último do homem. Porto Alegre: EPIDUCRS, 1998.

SÊNECA, Lúcio Aneu. Cartas a Lucílio. Madri: Fundação Calouste Gulbenkian, 1991.

. Sobre o ócio. Campinas: Nova Alexandrina, 1998.

SÉNECA, Lúceo Anneo. De la Cólera. Madrid: Alianza Editorial, 2000.

SILVA, Marilda Evangelista dos Santos. Sêneca o Humanista. Revista Caliopole, Rio de Janeiro, Ano 1, n. 1, p. 87-94, jul./dez. 1984.

USCATESCU, Jorge. Dimensión Humanística del pensamiento de Sêneca. In: CONGRESO INTERNACIONAL DE FILOSOFÍA, EN COMEMORACIÓN DE SÉNECA, en el XIX centanario de su muerte. Actas...Madrid: Taurus Ediciones, 1965.

VON RINTELEN, Fritz - Joachim. La unidade del género humano de Lucius Anneus Séneca. In: CONGRESO INTERNACIONAL DE FILOSOFÍA, en comemoración de Séneca, en el XIX centanario de su muerte. Actas... Madrid: Taurus Ediciones, 1965.

Data de registro 02/06/06 Data de aceite 20/12/06 